\title{
TITLE:
}

\section{Impact of Heterointerfaces in Solar Cells Using ZnSnP Bulk Crystals}

$\operatorname{AUTHOR}(\mathrm{S})$ :

Nakatsuka, Shigeru; Akari, Shunsuke; Chantana, Jakapan; Minemoto, Takashi; Nose, Yoshitaro

\section{CITATION:}

Nakatsuka, Shigeru ...[et al]. Impact of Heterointerfaces in Solar Cells Using ZnSnP Bulk Crystals. ACS Applied Materials \& Interfaces 2017, 9(39): 33827-33832

ISSUE DATE:

2017-10-04

URL:

http://hdl.handle.net/2433/243852

\section{RIGHT:}

This document is the Accepted Manuscript version of a Published Work that appeared in final form in 'ACS Applied Materials \& Interfaces', copyright $\odot$ American Chemical Society after peer review and technical editing by the publisher To access the final edited and published work see https://doi.org/10.1021/acsami.7b08852; The full-text file will be made open to the public on 12 September 2018 in accordance with publisher's 'Terms and Conditions for SelfArchiving'.; この論文は出版社版でありません。引用の際には出版社版をご確認ご利用ください。; This is not the published version. Please cite only the published version. 


\title{
Impact of hetero-interfaces in solar cells using $\mathrm{ZnSnP}_{2}$ bulk crystals
}

\author{
Shigeru Nakatsuka*1, Shunsuke Akari², Jakapan Chantana ${ }^{2}$, Takashi Minemoto ${ }^{2}$,
}

\section{Yoshitaro Nose ${ }^{1}$}

${ }^{1}$ Department of Materials Science and Engineering, Kyoto University, Kyoto 606-8501, Japan

${ }^{2}$ Department of Electrical and Electronic Engineering, Ritsumeikan University, Kusatsu, Shiga 527-8577, Japan

Keywords: Solar Cell, II-IV-V2, chalcopyrite, $\mathrm{ZnSnP}_{2}$, back electrode, etching

\footnotetext{
* To whom all correspondence should be addressed. Tel.: +81-75-753-5472; Fax: +81-75-753-3579; Email: nakatsuka.shigeru.25c@kyoto-u.jp
} 


\section{Abstract}

We report on the optimization of interface structure in $\mathrm{ZnSnP}_{2}$ solar cells. The effects of back electrode materials and related interface on photovoltaic performance were investigated. It was clarified that a conventional structure $\mathrm{Mo} / \mathrm{ZnSnP} 2$ showed a schottkybehaviour, while an ohmic-behaviour was observed in the $\mathrm{Cu} / \mathrm{ZnSnP} \mathrm{P}_{2}$ structure annealed at $300{ }^{\circ} \mathrm{C}$. STEM-EDX analysis suggested that $\mathrm{Cu}-\mathrm{Sn}-\mathrm{P}$ ternary compound was formed at the interface. This compound is considered to play an important role to obtain the ohmic contact between $\mathrm{ZnSnP}_{2}$ and $\mathrm{Cu}$. In addition, it was clarified that the aqua regia etching of $\mathrm{ZnSnP}_{2}$ bulk crystals before chemical bath deposition process for the preparation of buffer layer was effective to remove the layer including lattice defects introduced by mechanical-polishing, which was supported by TEM observations and photoluminescence measurements. This means that the carrier transport across the interface is improved due to the reduced defect at the interface. Consequently, the conversion efficiency of approximately $2 \%$ was achieved with the structure of $\mathrm{Al} / \mathrm{ZnO} ; \mathrm{Al} / \mathrm{ZnO} / \mathrm{CdS} / \mathrm{ZnSnP} / \mathrm{Cu}$, where the values of short circuit current density, $J_{\mathrm{SC}}$, open circuit voltage, $V_{\mathrm{OC}}$ and fill factor, $F F$, were $8.2 \mathrm{~mA} \mathrm{~cm}{ }^{-2}, 0.452 \mathrm{~V}$ and 0.533 , respectively. However, the value of $V_{\mathrm{OC}}$ was largely low considering the bandgap value of $\mathrm{ZnSnP}_{2}$. In order to improve the high conversion efficiency, the optimization of buffer layer material is considered to be essential in the viewpoint of band alignment. 


\section{Introduction}

Solar cells based on compound semiconductors have made large progress in late years.

Particularly, chalcogenide compounds such as $\mathrm{CuIn}_{1-x} \mathrm{Ga}_{x} \mathrm{Se}_{2}$ (CIGS) and CdTe have recorded high conversion efficiencies of $22.6^{1}$ and $22.1 \%{ }^{2}$, respectively. However, these compounds contain rare or toxic elements, which disturbs widespread use of the solar cells based on these compound semiconductors. Because of this situation, light absorbing materials which consists of safe and earth-abundant elements have been investigated and $\mathrm{Cu}_{2} \mathrm{ZnSnS}_{4-x} \mathrm{Se}_{x}$ recorded the conversion efficiency of $12.6 \%{ }^{3}$ For other instances, $\mathrm{Cu}_{2} \mathrm{SnS}_{3},{ }^{4} \mathrm{Cu}_{2} \mathrm{O},{ }^{5} \mathrm{SnS},{ }^{6} \mathrm{FeS}_{2},{ }^{7}$ and $\mathrm{Zn}_{3} \mathrm{P}_{2}{ }^{8}$ have been also investigated under the same concept.

In this work, $\mathrm{ZnSnP}_{2}$ is focused on as a solar absorbing material consisting of safe and earth-abundant elements. In the previous works, it was reported that $\mathrm{ZnSnP}_{2}$ showed a $p$ type conduction with the carrier concentration of $10^{16}-10^{18} \mathrm{~cm}^{-3}$ and a direct bandgap of $\sim 1.6 \mathrm{eV} \cdot{ }^{9-17}$ Based on Shockley-Queisser limit, ${ }^{13}$ the theoretical conversion efficiency of about $30 \%$ is calculated in the single-junction solar cell using $\mathrm{ZnSnP}_{2}$ under the condition of AM 1.5 G solar spectrum. ${ }^{14}$ The absorption coefficient of $\mathrm{ZnSnP}_{2}$ was reported to be approximately $10^{5} \mathrm{~cm}^{-1}$ in visible light range, ${ }^{14,15}$ which is comparable to that of CIGS. ${ }^{14,16}$. As mentioned above, $\mathrm{ZnSnP}_{2}$ has a promising properties for a solar absorbing 
material. However, in our previous works, $\mathrm{ZnSnP}_{2}$ solar cells with the structure of $\mathrm{Al} / \mathrm{AZO} / \mathrm{ZnO} / \mathrm{CdS} / \mathrm{ZnSnP}_{2} / \mathrm{Mo}$ were realized using bulk crystals. However, the conversion efficiency of the solar cells was only $0.087 \% .{ }^{17}$ In particular, the series resistance, evaluated from the gradient of $J-V$ characteristics in forward bias, was about $100 \Omega \mathrm{cm}^{2}$, which might lead to the low conversion efficiency. The resistance of $\mathrm{ZnSnP}_{2}$ bulk crystals was evaluated to be $3.5 \Omega \mathrm{cm}^{2}$, which was based on the resistivity and the thickness. ${ }^{11}$ Therefore, the large series resistance previously observed might be attributed to the resistance at the interface of $\mathrm{CdS} / \mathrm{ZnSnP}_{2}$ and/or $\mathrm{ZnSnP} / \mathrm{Mo}$. We thus investigated the structures of interfaces related to the absorbing material $\mathrm{ZnSnP}_{2}$ to clarify the origin of high resistance and improve the photovoltaic performance in $\mathrm{ZnSnP}_{2}$ solar cells.

\section{Experimental method}

\section{1. $\mathrm{ZnSnP}_{2}$ bulk crystal growth}

$\mathrm{ZnSnP}_{2}$ bulk crystals were grown by $\mathrm{Sn}$ flux method as reported in our previous work. ${ }^{11}$

The raw materials, Zn shots (99.99\%, Kojundo Chemical Laboratory), Sn shots (99.99\%, Kojundo Chemical Laboratory) and red phosphorus flacks (99.9999\%, Kojundo Chemical Laboratory) were sealed in evacuated quartz ampule with the inner diameter of $10 \mathrm{~mm}$ under the pressure of $10^{-2} \mathrm{~Pa}$. The nominal composition was controlled to be 92 mol\% $\mathrm{Sn}$ in $\mathrm{Sn}-\mathrm{ZnP}_{2}$ pseudo binary diagram. ${ }^{11}$ The total weight of sample was set at 
approximately $60 \mathrm{~g}$. Then, the quartz ampoule was set in vertical furnace and heated up to $700{ }^{\circ} \mathrm{C}$ for homogenization. After that, the furnace moved upward by the rate of 0.2 $\mathrm{mm} / \mathrm{h}$ and the sample was unidirectionally solidified from the bottom. The temperature of the bottom of the ampule was monitored by K-type thermocouple during crystal growth and the average cooling rate was approximately $0.7^{\circ} \mathrm{C} / \mathrm{h}$. After the crystal growth, bulk crystals were cut into several wafers in perpendicular to the growth direction. The surface of each wafer was mechanically polished with a series of emery papers and finally with $1 \mu \mathrm{m}$ diamond slurry on a buff sheet.

\subsection{Preparation of electrode/ $/ \mathrm{ZnSnP}_{2}$ samples}

In order to clarify the effects of back electrode and related interface in solar cells with the structure of $\mathrm{Al} / \mathrm{ZnO} ; \mathrm{Al}(\mathrm{AZO}) / \mathrm{ZnO} / \mathrm{CdS} / \mathrm{ZnSnP}_{2} / \mathrm{Mo}$, electrode/ZnSnP 2 samples were prepared. In this study, some metals with various work functions, ${ }^{18} \mathrm{Cu}(4.65 \mathrm{eV}), \mathrm{Ag}$ $(4.26 \mathrm{eV})$ and $\mathrm{Al}(4.28 \mathrm{eV})$ were investigated as an electrode in addition to Mo $(4.6 \mathrm{eV})$. Before preparation of the electrodes, $\mathrm{ZnSnP}_{2}$ bulk crystals were etched by immersing in $0.02 \mathrm{M}(=\mathrm{mol} / \mathrm{L}) \mathrm{Br}_{2}$ solution for $15 \mathrm{~min}$ to remove the surface oxides. The four electrodes with the diameter of $1 \mathrm{~mm}$ and the thickness of about $0.5 \mu \mathrm{m}$ were deposited on the etched surface to be square corners. $\mathrm{Cu}$ and Mo electrodes were formed by direct current (DC) sputtering technique using $\mathrm{Cu}$ (99.99\%, Furuuchi Chemical) and Mo (99.98\%, Furuuchi 
Chemical) target materials. Al and Ag electrodes were deposited by electron beam and resistive heating evaporation using Al shots (99.99\%, Furuuchi Chemical) and Ag wire (99.99\%, The Nilaco Corporation), respectively. After that, some samples were sealed in the evacuated quartz ampule below $10^{-2} \mathrm{~Pa}$ and annealed at 200 or $300{ }^{\circ} \mathrm{C}$ for 1 hour. Subsequently, current dependence of terminal resistance was measured using the resistivity/hall effect measurement system (ResiTest8300, Toyo Corporation). The crosssectional observation was carried out using scanning transmission electron microscopy with energy dispersive X-ray spectroscopy (STEM-EDX, JEM-2100F, JEOL) to observe interfacial structures. Samples for STEM were fabricated by focused ion beam process with Ga ion beam (FIB, SMI9200, SII).

\subsection{Fabrication of solar cells using $\mathrm{ZnSnP}_{2}$ bulk crystals}

The solar cell structure of $\mathrm{Al} / \mathrm{AZO} / \mathrm{ZnO} / \mathrm{CdS} / \mathrm{ZnSnP}_{2} / \mathrm{Cu}$ was adopted according to the experimental results in this work. The schematic illustration of the solar cells is shown in Figure 1. First of all, $\mathrm{Cu}$ back electrode with the thickness of approximately $0.5 \mu \mathrm{m}$ was prepared by DC sputtering on the polished surface of $\mathrm{ZnSnP}_{2}$ wafer with the diameter of about $6 \mathrm{~mm}$ and the thickness of about $200 \mu \mathrm{m}$. Before preparation of the electrodes, $\mathrm{ZnSnP}_{2}$ bulk crystals were etched by immersing in $0.02 \mathrm{M} \mathrm{Br}_{2}$ solution for $15 \mathrm{~min}$. After the preparation of $\mathrm{Cu}$ back electrode, some samples were sealed in the evacuated quartz 
ampoule below $10^{-2} \mathrm{~Pa}$ and annealed at $200^{\circ} \mathrm{C}$ for 1 hour or $300^{\circ} \mathrm{C}$ for $20 \mathrm{~min} . \mathrm{CdS}$ with the thickness of about $50 \mathrm{~nm}$ was prepared on the opposite surface to back electrode by chemical bath deposition (CBD) method, where the chemical bath contains $11 \mathrm{mM}$ of $\mathrm{CdSO}_{4}(99 \%$, SIGMA-ALDRICH), $2.3 \mathrm{M}$ of ammonia (28\%, Nacalai Tesque) and 56 $\mathrm{mM}$ of thiourea (98\%, Nakalai Tesque). The temperature and the deposition time were $80^{\circ} \mathrm{C}$ and $11 \mathrm{~min}$, respectively. In our previous work, it was suggested that the conduction band offset of $\mathrm{CdS} / \mathrm{ZnSnP}_{2}$ junction was about $-1.2 \mathrm{eV},{ }^{19}$ which is negatively large, “cliff' . In this study, CdS was used as a conventional and easily-obtained buffer material, although an appropriate material should be investigated to achieve higher conversion efficiency, which is a future work. Before preparation of $\mathrm{CdS}$ layer, the surface of $\mathrm{ZnSnP} 2$ bulk crystals was etched by immersing in $1 / 2$ or $1 / 4$ diluted aqua regia solution for $1-30$ min. The aqua regia solution was prepared using $\mathrm{HCl}\left(35 \%\right.$, Nacalai Tesque), $\mathrm{HNO}_{3}(60 \%$, Nacalai Tesque) and ultra-pure water. It was reported that aqua regia was necessary rather than conventional hydrochloric acid for etching of $\mathrm{ZnSnP}_{2}$ in our previous study. ${ }^{20} \mathrm{In}$ order to investigate the effects of etching, photoluminescence (PL) spectra of $\mathrm{ZnSnP}_{2}$ bulk crystals were measured at room temperature using the measurement system (Hamamatsu Photonics, C12132). The wavelength and the power of the excitation laser were $532 \mathrm{~nm}$ and $5.05 \mathrm{~mW}$, respectively. The area of the excitation laser beam was set at 
$0.5 \mathrm{~mm}^{2}$. Subsequently, $\mathrm{ZnO}$ and $\mathrm{AZO}$ films were formed on $\mathrm{CdS}$ layer by radio frequency $(\mathrm{RF})$ magnetron sputtering at room temperature with the thickness of 50 and $300 \mathrm{~nm}$, respectively. For the fabrication of $\mathrm{ZnO}$ and $\mathrm{AZO}$ films, $\mathrm{ZnO}$ (99.99\%, Furuuchi Chemical) and $\mathrm{ZnO}-2$ wt. $\% \mathrm{Al}_{2} \mathrm{O}_{3}(99.99 \%$, Furuuchi Chemical) were used as target materials. Finally, Al electrode with a grid pattern was fabricated by electron beam evaporation. The current density-voltage $(J-V)$ characteristics and the external quantum efficiency (EQE) of solar cells were investigated under the illumination conditions of 100 $\mathrm{mW} \mathrm{cm}^{-2}$ and $\mathrm{AM} 1.5 \mathrm{G}$ using the measurement system with solar simulator (Bunkoukeiki, CEP-25RR). The cross-sectional observation was performed using STEMEDX, where the samples were prepared by FIB.

\title{
3. Results and discussion
}

\subsection{Effect of back electrode materials on photovoltaic performance}

\author{
Generally, metals with larger work function than fermi level in $p$ type semicenductors
} are necessary for ohmic contact. Basically, it is necessary that work functions of metals are at deeper level than fermi level in p-type semiconductors for ohmic contacts at metal/p-type semiconductor interfaces. Hinuma et al. reported that the ionization potential of $\mathrm{ZnSnP}_{2}$, corresponding to the energy between vacuum level and valence band 
maximum, was calculated to be $5.53 \mathrm{eV}$ based on first principles calculation. ${ }^{21}$ And it is considered that $\mathrm{ZnSnP}$, $p$-type semiconductor, has its fermi level near the valence band maximum. From aboveConsidering the fermi level in $\mathrm{ZnSnP}_{2}$ near the valence band maximum because of $p$-type semiconductor, $\mathrm{Cu}(4.65 \mathrm{eV}), \mathrm{Ag}(4.26 \mathrm{eV})$ and $\mathrm{Al}(4.28$ $\mathrm{eV})$ and $\mathrm{Mo}(4.6 \mathrm{eV})^{18}$ seem to form schotkky contact with $\mathrm{ZnSnP}_{2}$.

Figure 2 shows the current dependence of terminal resistance. In the case of Mo with relatively large work function, $4.6 \mathrm{eV},{ }^{18}$ the terminal resistance decreases with increasing the current in both as-sputtered and annealed samples, which suggests the interface of $\mathrm{Mo} / \mathrm{ZnSnP} 2$ shows a Schottky behavior and leads to a high series resistance in solar cells. As shown in the supplemental materials, $\mathrm{Al}$ and $\mathrm{Ag}$ electrodes show the same tendency. The work functions of $\mathrm{Al}$ and $\mathrm{Ag}$ is 4.28 and $4.26 \mathrm{eV}$, respectively, ${ }^{18}$ which-are smaller compared with Mo. In the case of $\mathrm{Cu}$ shown in Figure $2 \mathrm{~b}$, the as-deposited sample also indicates a change of the terminal resistance, while the dependence of the resistance on current is smaller in the annealed samples. In particular, an ohmic behavior is observed in the sample annealed at $300{ }^{\circ} \mathrm{C}$, despite the work function of $\mathrm{Cu}$ is similar to that of Mo. ${ }^{18}$ This indicates that the resistance was affected by annealing at 200 and $300{ }^{\circ} \mathrm{C}$ unlike in the case of $\mathrm{Mo}$ and the interface of $\mathrm{Cu} / \mathrm{ZnSnP}_{2}$ is a more promising structure in solar cells using $\mathrm{ZnSnP}_{2}$ bulk crystals from the viewpoint of carrier transport. 
Figure 3 shows the cross-sectional STEM images and corresponding line profiles obtained by EDX analysis. In $\mathrm{Mo} / \mathrm{ZnSnP}_{2}$ as shown in Figure $3 \mathrm{a}$ and $\mathrm{b}$, the change of morphology and composition at the interface before and after annealing was not confirmed in $100 \mathrm{~nm}$ scale, which supports the results in the resistance measurements. On the other hand, in STEM images of $\mathrm{Cu} / \mathrm{ZnSnP}_{2}$, the measurable composition change due to interdiffusion at the interface was observed from the comparison between Figure $3 \mathrm{c}$ and $\mathrm{d}$, where the range of composition change was wider after annealing. The interfacial morphology also changed by annealing and particles considered to be intermediate compounds or precipitates were observed at the interface. In detailed observations, the remarkable change region of $\mathrm{Cu}, \mathrm{Sn}$ and $\mathrm{P}$ compositions in the composition profile coincides with the size of the particle in the STEM image. It is also understood that the particle does not contain $\mathrm{Zn}$. This fact implies the particle at the interface consists of a $\mathrm{Cu}-\mathrm{Sn}-\mathrm{P}$ ternary compound. In this system, ternary compound $\mathrm{Cu}_{4} \mathrm{SnP}_{10}$ was actually reported by Bullet and Dawson ${ }^{22}$. It is thus concluded that the ternary compound formation at the interface impacts the contact behaviour between back electrode and $\mathrm{ZnSnP}_{2}$. In the case of CIGS, it was also reported that the formation of $\mathrm{MoSe}_{2}$ was important to obtain the ohmic contact between Mo back electrode and CIGS absorber. ${ }^{23}$ However, as seen in Figure 3d, the region of the compound formation or the 
interdiffusion is locally limited at the $\mathrm{Cu} / \mathrm{ZnSnP} 2$ interface. Consequently, it has room for establishing of appropriate interfacial structure and processing for such a structure.

Then, the solar cells using $\mathrm{Cu}$ as a back electrode material were fabricated in order to investigate the effect of back electrode materials on photovoltaic performance. Figure 4 shows the $J-V$ characteristics of the solar cells with the structure of $\mathrm{Al} / \mathrm{AZO} / \mathrm{ZnO} / \mathrm{CdS} / \mathrm{ZnSnP}_{2} / \mathrm{Cu}$ with and without annealing. The solar cell parameters are summarized in Table 1 . The series resistances of the solar cells were roughly evaluated from the gradient of $J-V$ curves in forward bias. The remarkable reduction of series resistance and the improvement of cell performance were achieved by using $\mathrm{Cu}$ back electrode, comparing to the case of Mo with the series resistance of $\sim 100 \Omega \mathrm{cm}^{2}$ and the conversion efficiency of $0.09 \%$. It is also observed that the series resistance depends on the annealing conditions, which are consistent with the current dependence of terminal resistance shown in Figure 2. Consequently, the conversion efficiency of $0.27 \%$ was achieved. 


\subsection{Effects of aqua regia etching on $\mathrm{CdS} / \mathrm{ZnSnP}_{2}$ interface and photovoltaic performance}

In this study, $\mathrm{ZnSnP}_{2}$ crystals for solar cells were prepared by mechanical-polishing, which generally introduce some lattice defects such as vacancies and dislocation in crystals. An etching after polishing is carried out in conventional semiconductor processes for silicon. Before constructing solar cells, effects of etching on the crystal surface were investigated by PL measurements in this study. PL spectra before and after etching with 1/2 diluted aqua regia for various duration are shown in Figure 5. In each spectrum, the PL peak was observed at $\sim 740 \mathrm{~nm}$, corresponding to the bandgap of $\mathrm{ZnSnP}_{2}$. The peak intensity increased by etching with any conditions. We considered the etching at least for 10-15 min was sufficient from the viewpoint of PL measurements since the peak intensity seemed to be same in any duration except for $10 \mathrm{~min}$.

The cross-sectional STEM images of the solar cells with the structure of $\mathrm{Al} / \mathrm{AZO} / \mathrm{ZnO} / \mathrm{CdS} / \mathrm{ZnSnP}_{2} / \mathrm{Cu}$ without and with etching by $1 / 2$ diluted aqua regia for 15 min are shown in Figure 6. The etching of $\mathrm{ZnSnP}_{2}$ crystals was carried out before the preparation of $\mathrm{CdS}$. The $\mathrm{Cu}$ back electrode optimized in this study was used. A contrast due to lattice strain was actually observed in the $\mathrm{ZnSnP}_{2}$ bulk crystal near the interface of $\mathrm{CdS} / \mathrm{ZnSnP}{ }_{2}$ as shown in Figure 6a. As previously mentioned, when preparing $\mathrm{ZnSnP}_{2}$ 
crystals for solar cells, the surface was mechanically polished, which might introduce some lattice defects. A region including defects generally makes higher the recombination rate of minority carriers and lower performance of solar cells. On the other hand, a strain contrast is not observed, and the smooth interface and the thin layer of CdS are clearly confirmed in the etched sample shown in Figure 6b. This image suggests that a region including defects was removed by etching under the above condition as expected.

The illuminated and dark $J-V$ characteristics of the solar cells are shown in Figure 7a and $b$ when etched under various conditions. The solar cell parameters are summarized in Table 2. The etching using aqua regia improved all cell parameters such as short circuit current density, $J_{\mathrm{SC}}$, open circuit voltage, $V_{\mathrm{OC}}$ and fill factor, $F F . J_{\mathrm{SC}}$ is almost same value in any samples etched with $1 / 2$ diluted aqua regia, while $F F$ increases with increasing duration, which leads to an increase of Voc. Consequently, the conversion efficiency of approximately $2 \%$ was achieved in the cell etched for $15 \mathrm{~min}$, where $J_{\mathrm{SC}}, V_{\mathrm{OC}}$ and $F F$ were $8.2 \mathrm{~mA} \mathrm{~cm}^{-2}, 0.452 \mathrm{~V}$ and 0.533 , respectively. These results are considered to come from the removing of lattice defects by etching. However, the performance degraded in the sample with longer etching of $30 \mathrm{~min}$, since the shunt resistance decreased as shown in Figure 7b. While, significant leakage was not observed in dark characteristics of other samples. 
It is speculated that grain boundary in $\mathrm{ZnSnP}_{2}$ crystal was preferentially etched and a part of the solar cells was short-circuit since $\mathrm{ZnSnP}_{2}$ crystals composed of grains with the size of submillimeter. In the sample etched using 1/4 diluted aqua regia for $15 \mathrm{~min}$, the significant improvement of photovoltaic performance was not observed compared with samples with $1 / 2$ diluted aqua regia etching, which suggested that the etching condition was insufficient to remove the layer including defects.

Figure 8a and $\mathrm{b}$ show the EQE spectra of the solar cells without and with $1 / 2$ diluted aqua regia etching for 15 min under various applied voltages of $0,-0.5$ and $-1 \mathrm{~V}$, respectively. In conventional solar cells with high efficiency, EQE spectra are independent of applied reverse bias, while it is observed that EQE curves drastically change and the values increase with increasing the applied reverse bias in the sample without etching. One of the reasons for such a behavior in EQE spectra is a high recombination rate of light-induced minority carriers due to lattice defects near the interface of $\mathrm{CdS} / \mathrm{ZnSnP} 2$ as shown in Figure 6a. In the sample with etching, the voltage dependence of EQE spectra is smaller and EQE at $0 \mathrm{~V}$ is larger than that without etching. The above behavior in EQE spectra indicates the improvement of carrier transport at the interface between $\mathrm{CdS}$ and $\mathrm{ZnSnP}_{2}$ due to removing regions including defects, which leads to higher efficiency. However, the maximum EQE under the voltage of $-1.0 \mathrm{~V}$ was 
about 0.6, which was lower compared with the sample without etching. The details of this decrease in the EQE spectra must be investigated in future works.

Here, the maximum $V_{\mathrm{OC}}$ in this study is $0.45 \mathrm{~V}$, which is lower considering the bandgap of $\mathrm{ZnSnP}_{2}$. In our previous work, it was suggested that the conduction band offset of $\mathrm{CdS} / \mathrm{ZnSnP} 2$ junction was about $-1.2 \mathrm{eV}$, which is negatively large conduction band offset, "cliff"' and limited the $V_{\text {OC. }}{ }^{19}$ Therefore, the optimization of buffer layer material is thus essential to achieve higher conversion efficiency in $\mathrm{ZnSnP}_{2}$ solar cells from the viewpoint of band alignment. 


\section{Conclusions}

In this study, we focused on the interfaces in $\mathrm{ZnSnP}_{2}$ solar cells for high efficiency.

The effects of back electrode materials, $\mathrm{Mo}, \mathrm{Cu}, \mathrm{Ag}$ and $\mathrm{Al}$, and related interfaces on photovoltaic performance were investigated. It was clarified that $\mathrm{Mo} / \mathrm{ZnSnP}_{2}$ showed a schottky behavior and Mo was unsuitable for back electrode material in $\mathrm{ZnSnP}_{2}$ solar cells. This schottky-contact between $\mathrm{Mo}$ and $\mathrm{ZnSnP}_{2}$ is one of the reasons that the high series resistance was observed in the solar cells with the structure of $\mathrm{Al} / \mathrm{AZO} / \mathrm{ZnO} / \mathrm{CdS} / \mathrm{ZnSnP} / \mathrm{Mo}$. The junctions using $\mathrm{Ag}$ and $\mathrm{Al}$ also show Schottky behavior. On the other hand, the ohmic contact was obtained for the $\mathrm{Cu} / \mathrm{ZnSnP} 2$ structure annealed at $300{ }^{\circ} \mathrm{C}$. The cross-sectional STEM-EDX analyses suggested that $\mathrm{Cu}-\mathrm{Sn}-\mathrm{P}$ ternary compound was formed at the interface of the annealed $\mathrm{Cu} / \mathrm{ZnSnP} 2$ structure. This compound might be important to obtain the ohmic contact between $\mathrm{ZnSnP}_{2}$ and $\mathrm{Cu}$.

For the interface between $\mathrm{CdS}$ and $\mathrm{ZnSnP}_{2}$, a strain contrast due to lattice defects introduced by mechanically-polishing was observed in the cross-sectional TEM image. In this study, it was revealed that the aqua regia etching of $\mathrm{ZnSnP}_{2}$ bulk crystals before CBD process removed the layer including lattice defects, which improved $\mathrm{FF}$ and $V_{\text {oc. }}$ Consequently, the conversion efficiency of approximately $2 \%$ was achieved with the structure of $\mathrm{Al} / \mathrm{AZO} / \mathrm{ZnO} / \mathrm{CdS} / \mathrm{ZnSnP}_{2} / \mathrm{Cu}$, where the values of $J_{\mathrm{SC}}, V_{\mathrm{OC}}$ and $F F$ were 8.2 
$\mathrm{mA} \mathrm{cm}{ }^{-2}, 0.452 \mathrm{~V}$ and 0.533 , respectively. However, longer etching reduced the cell performance because of shunting. The preferential dissolution of area around grain boundary in $\mathrm{ZnSnP}_{2}$ crystals during etching is considered and further investigation is necessary to clarify the mechanism.

In addition, $V_{\mathrm{OC}}$ of the cells prepared in this study were quite low considering the bandgap of $\mathrm{ZnSnP}_{2}$. For further improvement of the conversion efficiency, the optimization of band alignment is considered to be essential by developing appropriate buffer materials.

\section{Supporting Information}

The Supporting Information is available free of charge on the ACS Publications web site at DOI:

Further information relating to the current dependence of terminal resistance in $\mathrm{Al} / \mathrm{ZnSnP}{ }_{2}$ and $\mathrm{Ag} / \mathrm{ZnSnP}{ }_{2}$ samples.

\section{Acknowledgements}

This work was financially supported by Grant-in-Aid for JSPS Research Fellow Number 16J09443. 


\section{References}

(1) Jackson, P.; Wuerz, R.; Hariskos, D.; Lotter, E.; Witte, W.; Powalla, M. Effects of Heavy Alkali Elements in $\mathrm{Cu}(\mathrm{In}, \mathrm{Ga}) \mathrm{Se}_{2}$ Solar Cells with Efficiencies up to $22.6 \%$ Phys. Status Solidi RRL 2016, 10, 583-586.

(2) First Solar press release, Fist Solar Hits Record 22.1\% Conversion Efficiency for CdTe Solar Cell, https://www.greentechmedia.com/articles/read/First-Solar-HitsRecord-22.1-Conversion-Efficiency-For-CdTe-Solar-Cell (last accessed June 2017).

(3) Wang, W.; Winkler, M. T.; Gunawan, O.; Gokmen, T.; Todorov, T. K.; Zhu, Y.; Mitzi, D. B. Device Characteristics of CZTSSe Thin-Film Solar Cells with $12.6 \%$ Efficiency Adv. Energy Mater. 2013, 4, 1301465.

(4) Nakashima, M.; Fujimoto, J.; Yamaguchi, T.; Izaki, M. $\mathrm{Cu}_{2} \mathrm{SnS}_{3}$ Thin-Film Solar Cells Fabricated by Sulfurization from NaF/Cu/Sn Stacked Precursor Appl. Phys. Express 2015, 8, 042303.

(5) Minami, T.; Nishi, Y.; Miyata, T. Heterojunction Solar Cell with 6\% Efficiency Based on an N-Type Aluminum-Gallium-Oxide Thin Film and P-Type SodiumDoped $\mathrm{Cu}_{2} \mathrm{O}$ Sheet Appl. Phys. Express 2015, 8, 022301.

(6) Sinsermsuksakul, P.; Sun, L.; Lee, S. W.; Park, H. H.; Kim, S. B.; Yang, C.; 
Gordon, R. G. Overcoming Efficiency Limitations of SnS-Based Solar Cells Adv. Energy Mater. 2014, 4, 1400496.

(7) Ennaoui, A.; Tributsch, H. Iron Sulphide Solar Cells Sol. Cells 1984, 13, 197-200.

(8) Bhushan, M.; Catalano, A. Polycrystalline $\mathrm{Zn}_{3} \mathrm{P}_{2}$ Schottky Barrier Solar Cells Appl. Phys. Lett. 1981, 38, 39-41.

(9) Abdurakhimov, A. A.; Kradinova, L. V.; Parimbekov, Z. A.; Rud', Y. V. Schottky Diodes Made of P-Type $\mathrm{ZnSnP}_{2}$ Sov. Phys. Semicond. 1982, 16, 156-159.

(10) Ryan, M. A.; Peterson, M. W.; Williamson, D. L.; Frey, J. S.; Maciel, G. E.; Parkinson, B. A. Metal Site Disorder in Zinc Tin Phosphide J. Mater. Res. 1987, $2,528-537$.

(11) Nakatsuka, S.; Nakamoto, H.; Nose, Y.; Uda, T.; Shirai, Y. Bulk Crystal Growth and Characterization of $\mathrm{ZnSnP}_{2}$ Compound Semiconductor by Flux Method Phys. Status Solidi C 2015, 12, 520-523.

(12) Scanlon, D. O.; Walsh, A. Bandgap Engineering of $\mathrm{ZnSnP}_{2}$ for High-Efficiency Solar Cells Appl. Phys. Lett. 2012, 100, 251911.

(13) Shockley, W.; Queisser, H. J. Detailed Balance Limit of Efficiency of PN Junction Solar Cells J. Appl. Phys. 1961, 32, 510-519.

(14) Yokoyama, T.; Oba, F.; Seko, A.; Hayashi, H.; Nose, Y.; Tanaka, I. Theoretical 
Photovoltaic Conversion Efficiencies of $\mathrm{ZnSnP}_{2}, \mathrm{CdSnP}_{2}$, and $\mathrm{Zn}_{1-x} \mathrm{Cd}_{x} \mathrm{SnP}_{2}$ Alloys Appl. Phys. Express 2013, 6, 061201.

(15) Shin, H. Y.; Ajmera, P. K. Characterization of Vacuum Grown Thin Films of $\mathrm{ZnSnP}_{2}$ Mater. Lett. 1987, 5, 211-214.

(16) Minoura, S.; Kodera, K.; Maekawa, T.; Miyazaki, K.; Niki, S.; Fujiwara, H. Dielectric Function of $\mathrm{Cu}(\mathrm{In}, \mathrm{Ga}) \mathrm{Se}_{2}$-Based Polycrystalline Materials J. Appl. Phys. 2013, 113, 063505.

(17) Nakatsuka, S.; Yuzawa, N.; Chantana, J.; Minemoto, T.; Nose, Y. ZnSnP 2 ThinFilm Solar Cell Prepared by Phosphidation Method under Optimized Zn/Sn Atomic Ratio of its Absorbing Layer Phys. Status Solidi A 2017, 214, 1600650.

(18) Michaelson, H. B. The Work Function of the Elements and its Periodicity 1977, $48,4729-4733$.

(19) Nakatsuka, S.; Nose, Y.; Shirai, Y. Band Offset at the Heterojunction of $\mathrm{CdS} / \mathrm{ZnSnP}{ }_{2}, \mathrm{ZnS} / \mathrm{ZnSnP}_{2}$, and $\mathrm{In}_{2} \mathrm{~S}_{3} / \mathrm{ZnSnP}_{2}$ J. Appl. Phys. 2016, 119, 193107.

(20) Nakatsuka, S. Fabrication of bulk crystal and thin film of II-IV-V 2 type compound semiconductor $\mathrm{ZnSnP}_{2}$ for photovoltaic application, Ph.D. Thesis, Kyoto University, Kyoto, Japan, 2017.

(21) Hinuma, Y.; Oba, F.; Nose, Y.; Tanaka, I. First-Principles Study of Valence Band 
Offsets at $\mathrm{ZnSnP}_{2} / \mathrm{CdS}, \mathrm{ZnSnP}_{2} / \mathrm{ZnS}$, and Related Chalcopyrite/Zincblende

Heterointerfaces J. Appl. Phys. 2013, 114 (4).

(22) Bullet, D. W.; Dawson, W. G. Bonding in the Ternary Copper Tin Phosphide $\mathrm{Cu}_{4} \mathrm{SnP}_{10}$ Solid State Commun. 1986, 60, 767-769.

(23) Wada, T.; Kohara, N.; Nishiwaki, S.; Negami, T. Characterization of the $\mathrm{Cu}(\mathrm{In}, \mathrm{Ga}) \mathrm{Se}_{2} / \mathrm{Mo}$ Interface in CIGS Solar Cells Thin Solid Films 2001, 387, 118122. 


\section{Figure captions}

Figure 1. Schematic illustration of $\mathrm{ZnSnP}_{2}$ solar cells with the structure of

$\mathrm{Al} / \mathrm{AZO} / \mathrm{ZnO} / \mathrm{CdS} / \mathrm{ZnSnP}_{2} / \mathrm{Cu}$.

Figure 2. Current dependence of terminal resistance in samples as-prepared and annealed at 200 and $300{ }^{\circ} \mathrm{C}$ for 1 hour. (a) Mo and (b) Cu electrodes.

Figure 3. Cross-sectional STEM-DF images and corresponding EDX profiles of $\mathrm{Mo} / \mathrm{ZnSnP} \mathrm{P}_{2}$ (a) without annealing and (b) annealed at $300{ }^{\circ} \mathrm{C}$ for 1 hour, and $\mathrm{Cu} / \mathrm{ZnSnP} 2$

(c) without annealing and (d) annealed at $300{ }^{\circ} \mathrm{C}$ for 1 hour. The gray frameworks in STEM-DF images show the area analysed by EDX.

Figure 4. $J-V$ characteristics of the solar cells with the structure of $\mathrm{Al} / \mathrm{AZO} / \mathrm{ZnO} / \mathrm{CdS} / \mathrm{ZnSnP}_{2} / \mathrm{Cu}$ with and without annealing at 200 or $300{ }^{\circ} \mathrm{C}$. Annealing was performed after the $\mathrm{Cu}$ back electrode was formed.

Figure 5. Photoluminescence spectra of $\mathrm{ZnSnP}_{2}$ bulk crystals before and after $1 / 2$ diluted aqua regia etching for various duration. 
Figure 6. Cross-sectional TEM images of $\mathrm{ZnSnP}_{2}$ solar cells (a) without etching and (b) with aqua regia etching.

Figure 7. (a) $J-V$ characteristics of $\mathrm{ZnSnP}_{2}$ solar cells with and without aqua regia etching under (a) illuminated and (b) dark conditions. In these solar cells, $\mathrm{Cu}$ electrode annealed at $300{ }^{\circ} \mathrm{C}$ was used.

Figure 8. (a)-EQE spectra of $\mathrm{ZnSnP}_{2}$ solar cells (a) without etching and (b) with $1 / 2$ diluted aqua regia etching for $15 \mathrm{~min}$, under various applied voltages. In these solar cells, $\mathrm{Cu}$ electrode annealed at $300^{\circ} \mathrm{C}$ was used. 
- Figures

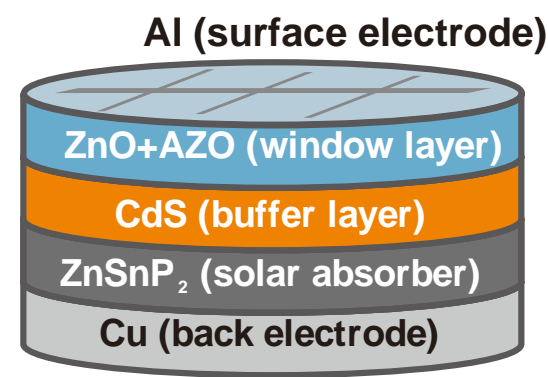

Figure 1. Schematic illustration of $\mathrm{ZnSnP}_{2}$ solar cells with the structure of $\mathrm{Al} / \mathrm{AZO} / \mathrm{ZnO} / \mathrm{CdS} / \mathrm{ZnSnP}_{2} / \mathrm{Cu}$. 

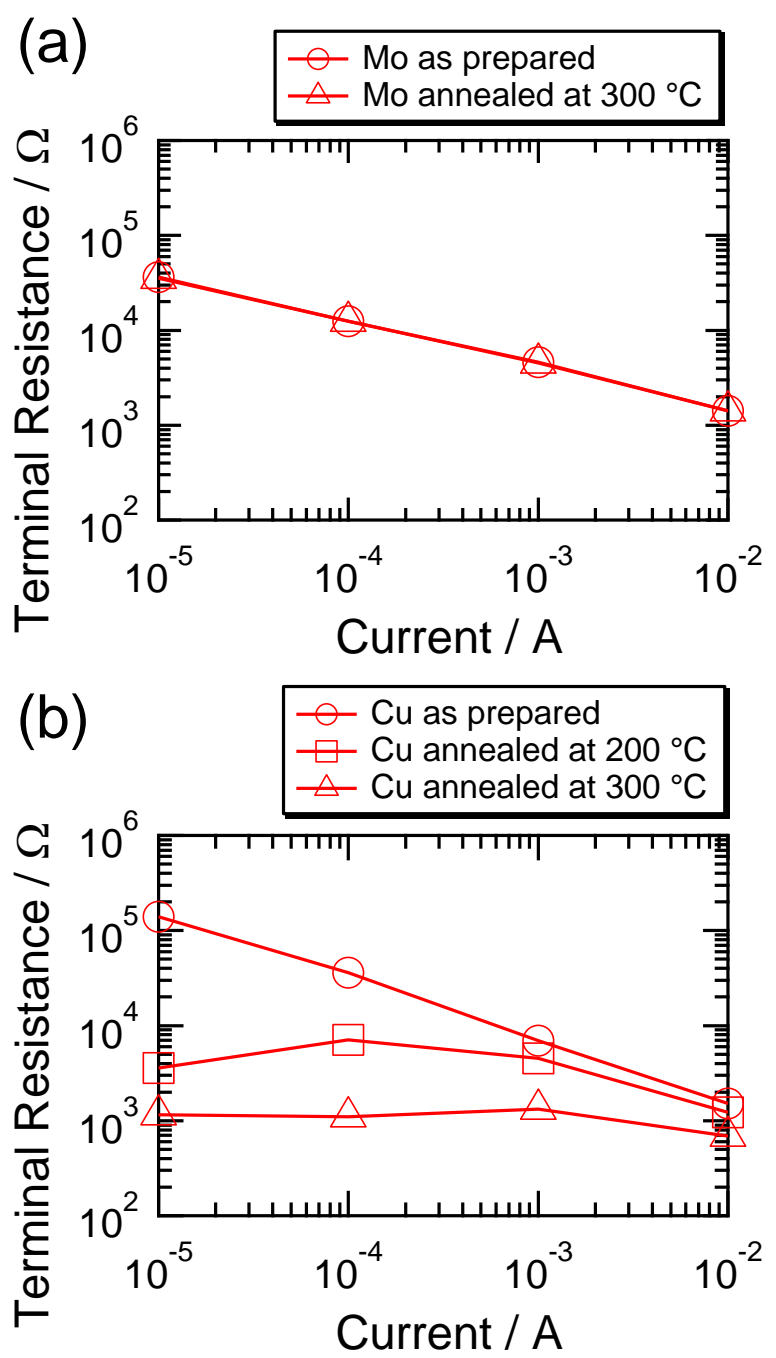

Figure 2. Current dependence of terminal resistance in samples as-prepared and annealed at 200 and $300{ }^{\circ} \mathrm{C}$ for 1 hour. (a) Mo and (b) Cu electrodes. 

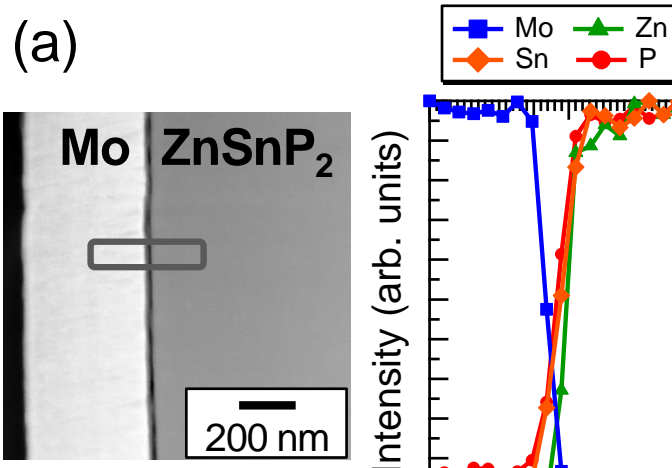

(b)
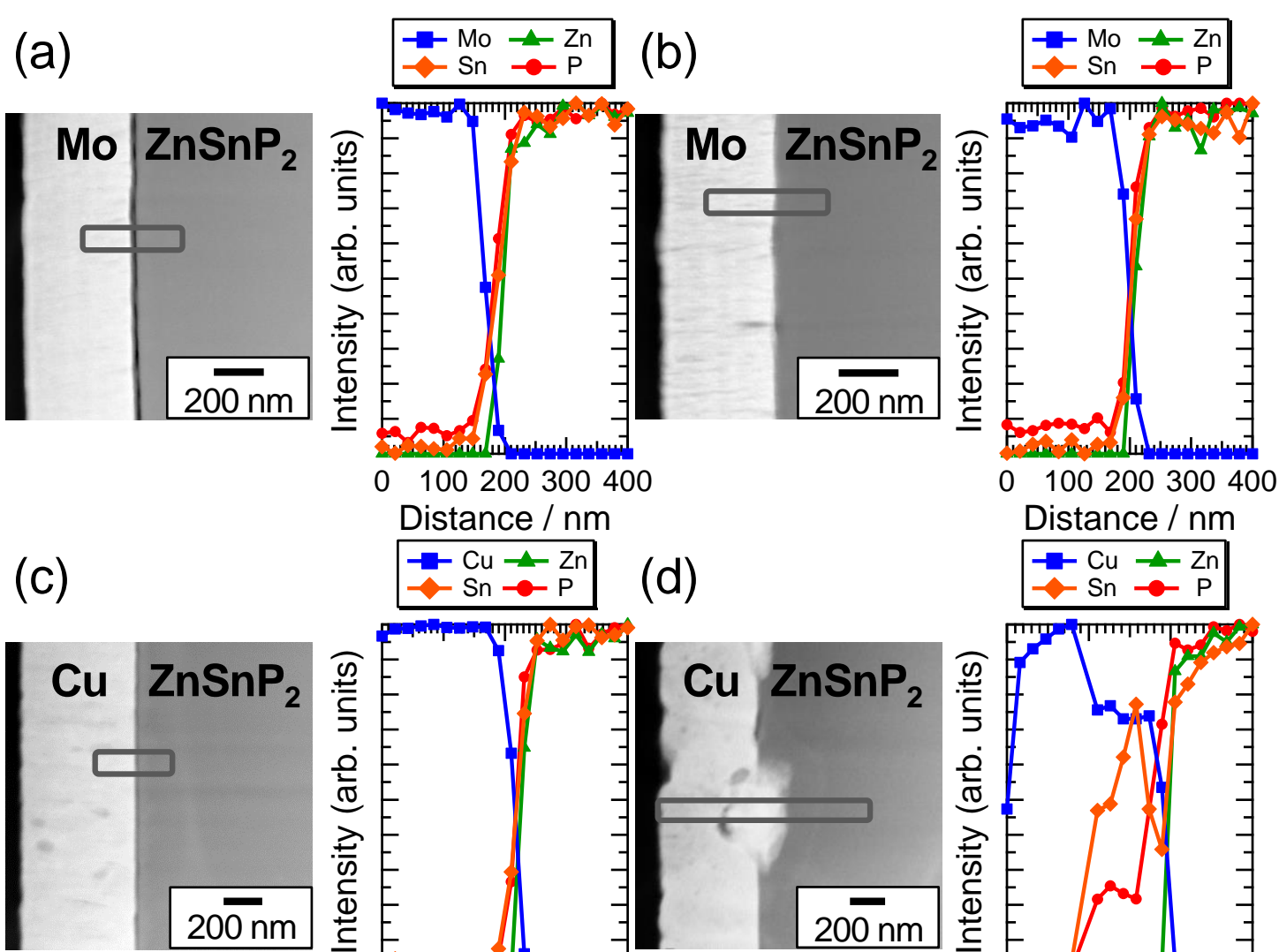

Distance / $\mathrm{nm}$

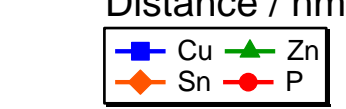

(d)
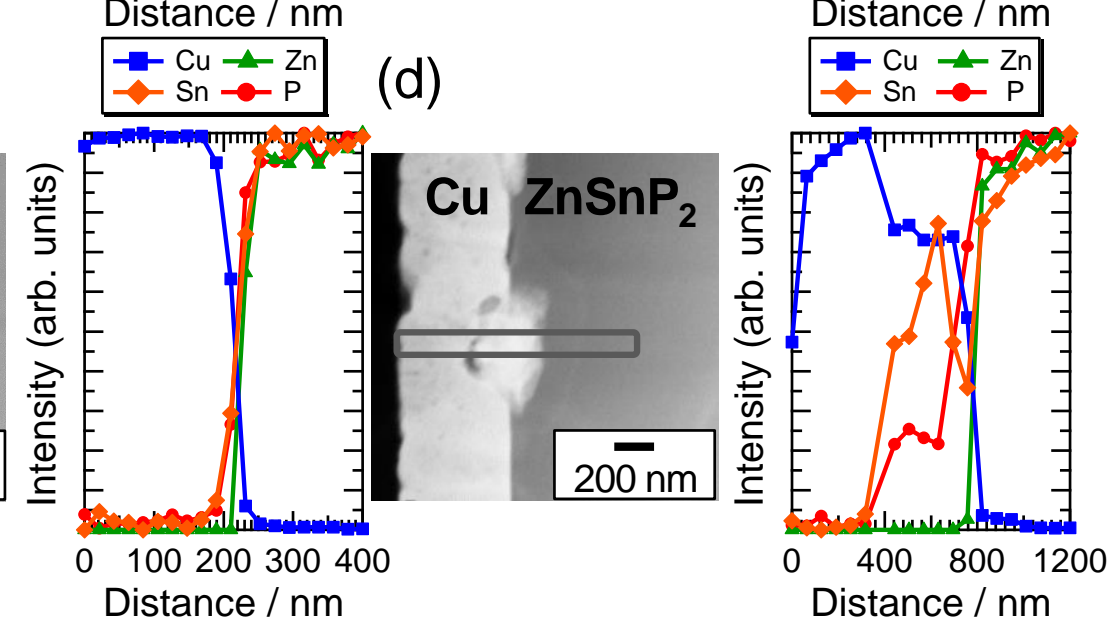

Figure 3. Cross-sectional STEM-DF images and corresponding EDX profiles of $\mathrm{Mo} / \mathrm{ZnSnP} 2$ (a) without annealing and (b) annealed at $300{ }^{\circ} \mathrm{C}$ for 1 hour, and $\mathrm{Cu} / \mathrm{ZnSnP} 2$ (c) without annealing and (d) annealed at $300{ }^{\circ} \mathrm{C}$ for 1 hour. The gray frameworks in STEM-DF images show the area analysed by EDX. 


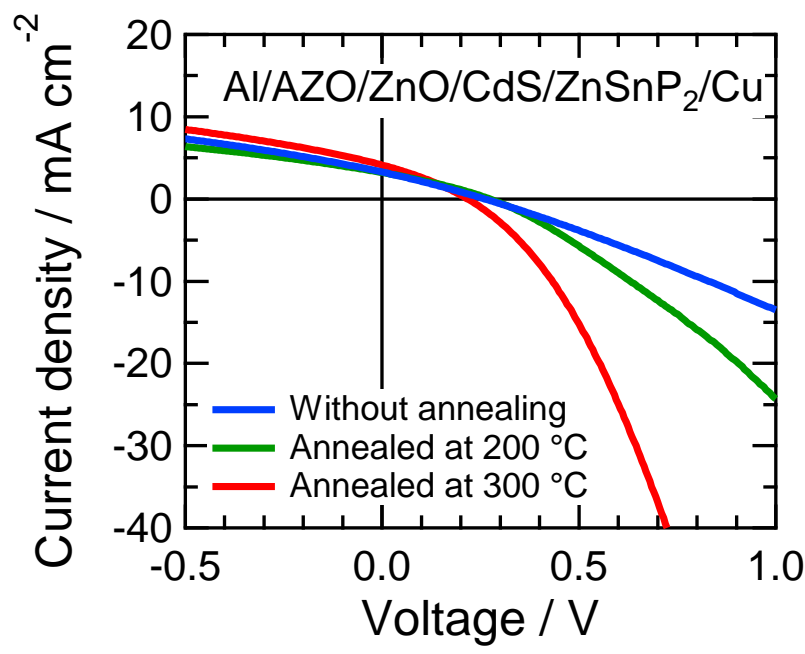

Figure 4. $J-V$ characteristics of the solar cells with the structure of $\mathrm{Al} / \mathrm{AZO} / \mathrm{ZnO} / \mathrm{CdS} / \mathrm{ZnSnP}_{2} / \mathrm{Cu}$ with and without annealing at 200 or $300{ }^{\circ} \mathrm{C}$. Annealing was performed after the $\mathrm{Cu}$ back electrode was formed. 


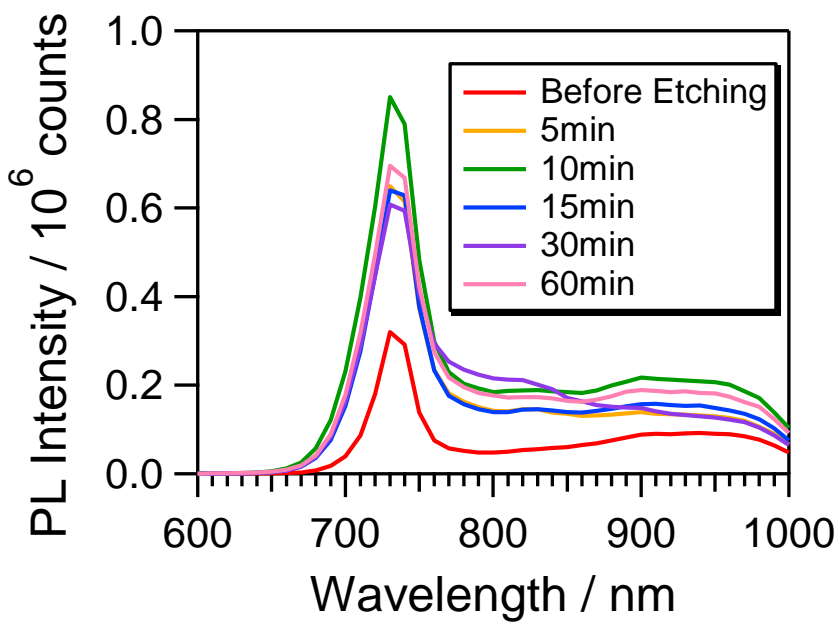

Figure 5. Photoluminescence spectra of $\mathrm{ZnSnP}_{2}$ bulk crystals before and after $1 / 2$ diluted aqua regia etching for various duration. 


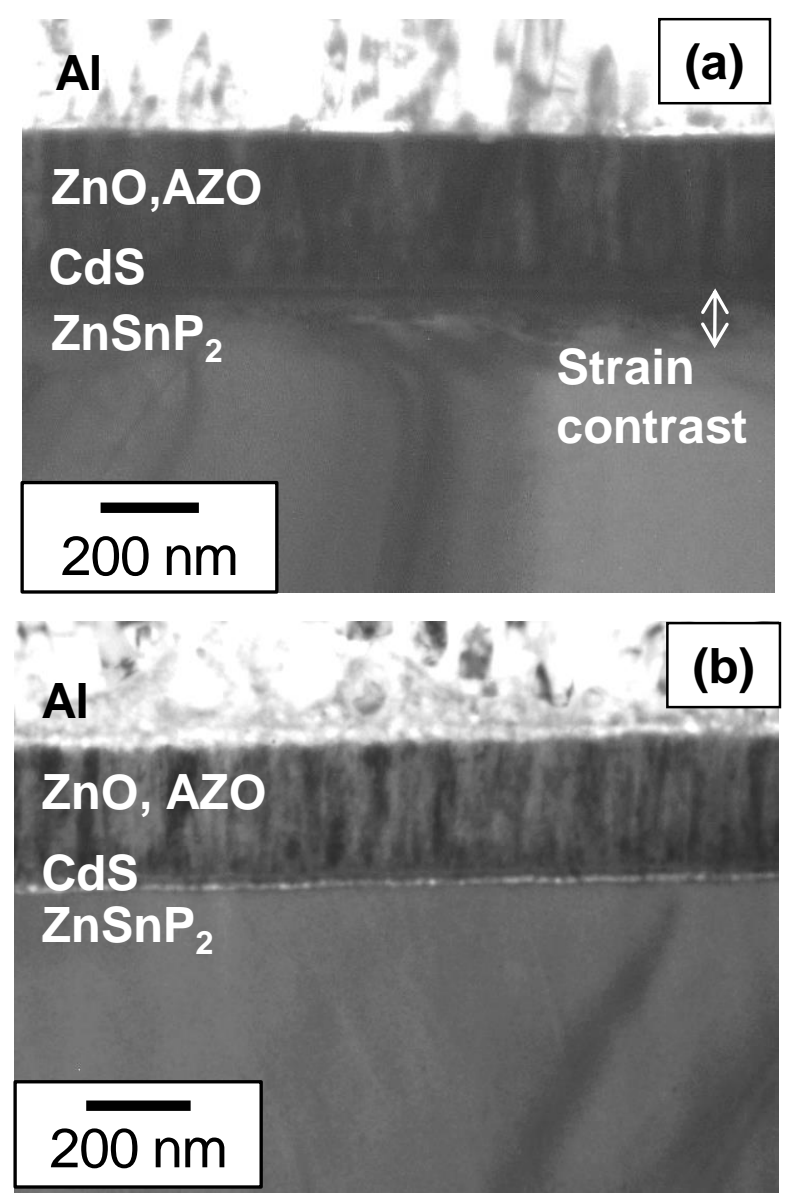

Figure 6. Cross-sectional TEM images of $\mathrm{ZnSnP}_{2}$ solar cells (a) without etching and (b) with aqua regia etching. 


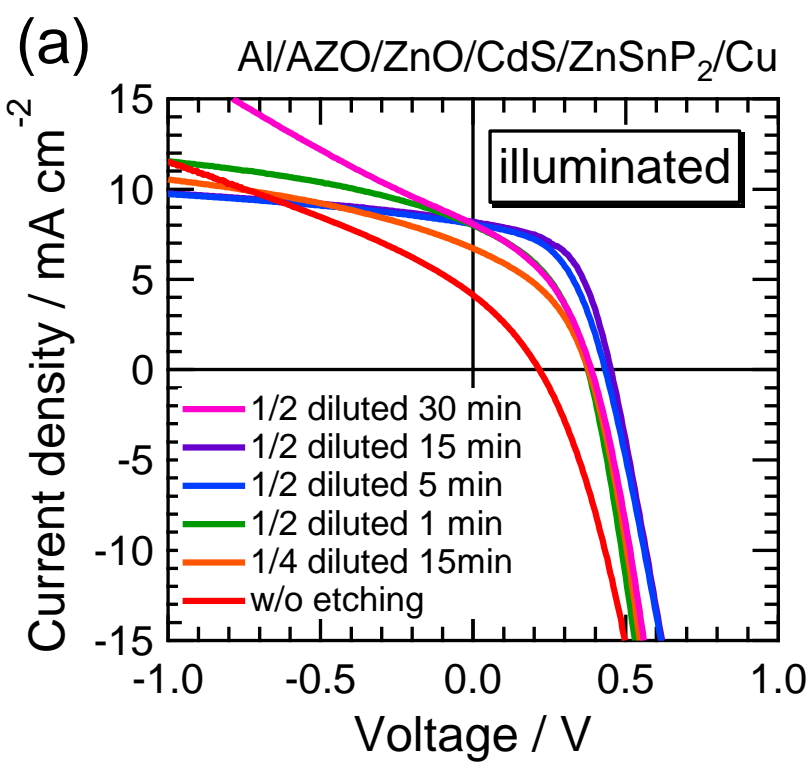

(b) $\quad \mathrm{Al} / \mathrm{AZO} / \mathrm{ZnO} / \mathrm{CdS} / \mathrm{ZnSnP}_{2} / \mathrm{Cu}$

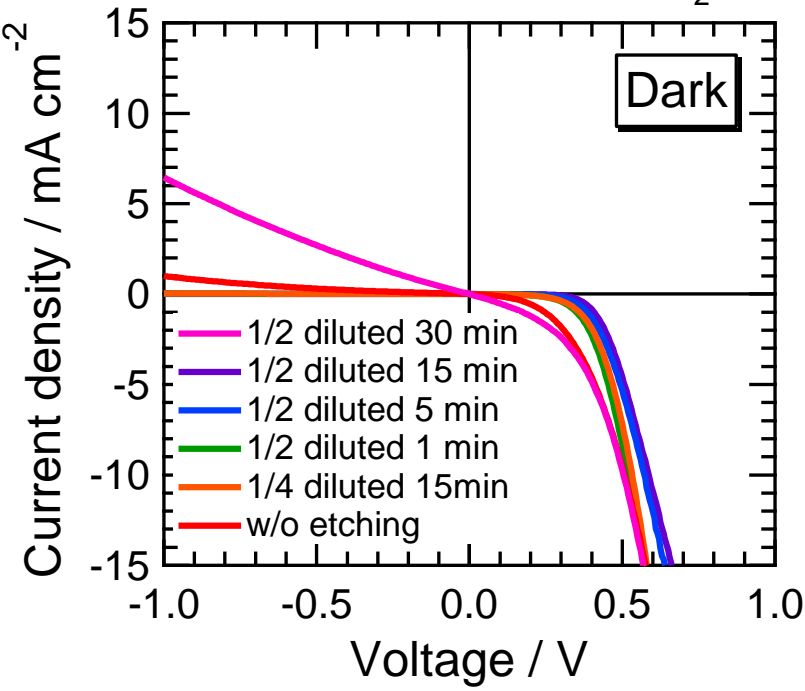

Figure 7. (a) $J-V$ characteristics of $\mathrm{ZnSnP}_{2}$ solar cells with and without aqua regia etching under (a) illuminated and (b) dark conditions. In these solar cells, $\mathrm{Cu}$ electrode annealed at $300{ }^{\circ} \mathrm{C}$ was used. 
(a)

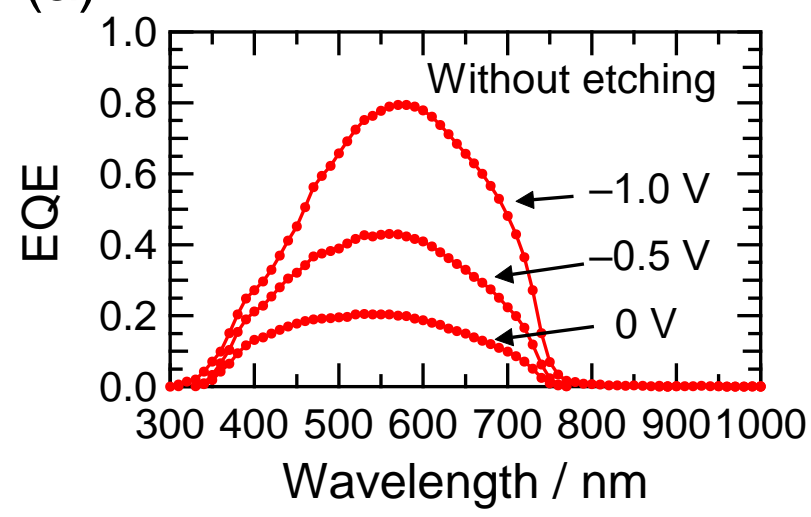

(b)

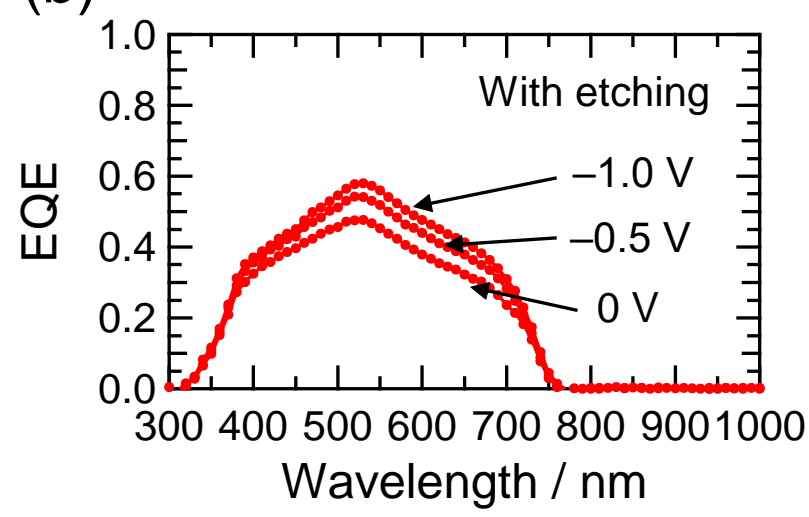

Figure 8. (a) $\mathrm{EQE}$ spectra of $\mathrm{ZnSnP}_{2}$ solar cells (a) without etching and (b) with $1 / 2$ diluted aqua regia etching for $15 \mathrm{~min}$, under various applied voltages. In these solar cells, $\mathrm{Cu}$ electrode annealed at $300{ }^{\circ} \mathrm{C}$ was used. 
- Tables

Table 1. Solar cell parameters of $\mathrm{ZnSnP}_{2}$ solar cells with $\mathrm{Cu}$ back electrode.

\begin{tabular}{cccccc}
\hline & $\begin{array}{c}J_{\mathrm{SC}} \\
/ \mathrm{mA} \mathrm{cm}^{-2}\end{array}$ & $\begin{array}{c}V_{\mathrm{OC}} \\
/ \mathrm{V}\end{array}$ & $F F$ & $\begin{array}{c}\text { Efficiency } \\
/ \%\end{array}$ & $\begin{array}{c}R_{\mathrm{s}} \\
/ \Omega \mathrm{cm}^{2}\end{array}$ \\
\hline $\begin{array}{c}\mathrm{Cu} \text { as deposited } \\
\mathrm{Cu} 200^{\circ} \mathrm{C}, \\
\begin{array}{c}\text { 1hour, } \\
\text { annealed }\end{array}\end{array}$ & 3.3 & 0.261 & 0.27 & 0.23 & $\sim 50$ \\
$\begin{array}{c}\mathrm{Cu} 300{ }^{\circ} \mathrm{C}, \\
\text { 1hour, } \\
\text { annealed }\end{array}$ & 3.2 & 0.274 & 0.30 & 0.26 & $\sim 25$ \\
\hline
\end{tabular}

Table 2. Solar cell parameters of $\mathrm{ZnSnP}_{2}$ solar cells with and without aqua regia etching.

\begin{tabular}{lccccc}
\hline & $\begin{array}{c}J_{\mathrm{SC}} \\
/ \mathrm{mA} \mathrm{cm}\end{array}$ & $\begin{array}{c}V_{\mathrm{OC}} \\
/ \mathrm{V}\end{array}$ & $F F$ & $\begin{array}{c}\text { Efficiency } \\
/ \%\end{array}$ & $\begin{array}{c}R_{\mathrm{S}} \\
/ \Omega \mathrm{cm}^{2}\end{array}$ \\
\hline $\begin{array}{l}1 / 2 \text { diluted } \\
\text { for 30 min }\end{array}$ & 8.1 & 0.387 & 0.393 & 1.23 & $\sim 8$ \\
$\begin{array}{l}1 / 2 \text { diluted } \\
\text { for 15 min } \\
1 / 2 \text { diluted } \\
\text { for 5 min }\end{array}$ & 8.2 & 0.452 & 0.533 & 1.97 & $\sim 11$ \\
$\begin{array}{l}1 / 2 \text { diluted } \\
\text { for 1 min } \\
1 / 4 \text { diluted } \\
\text { for 15 min }\end{array}$ & 8.1 & 0.433 & 0.496 & 1.73 & $\sim 11$ \\
w/o etching & 8.0 & 0.376 & 0.416 & 1.25 & $\sim 8$ \\
\hline
\end{tabular}




\section{- Tables of Contents}

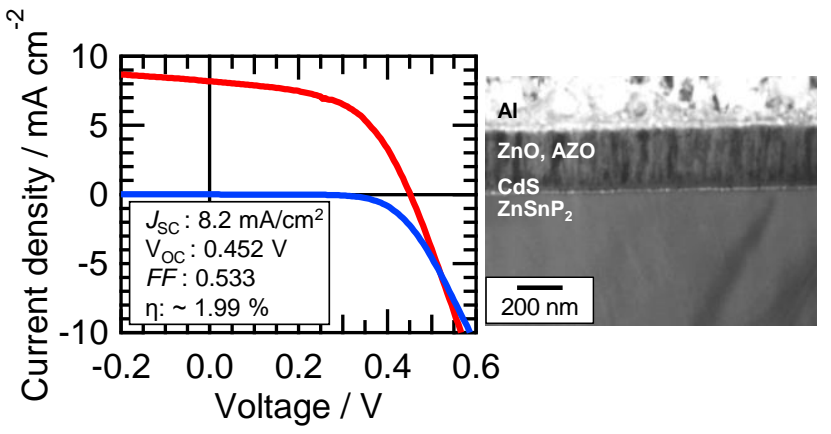

